\title{
Evaluation of health conditions of leaves of Japanese knotweed (Reynoutria japonica Houtt.) in selected locations of Tatra National Park and Wigry National Park
}

\author{
Ocena zdrowotności liści rdestowca ostrokończystego \\ (Reynoutria japonica Houtt.) w wybranych lokalizacjach \\ Tatrzańskiego Parku Narodowego i Wigierskiego Parku Narodowego
}

\author{
Wojciech Pusz ${ }^{1 *}$, Anna Baturo-Cieśniewska², Katarzyna Patejuk ${ }^{1}$, Tomasz Zwijacz-Kozica³
}

\section{Summary}

Phytopathological studies on health conditions of leaves of Japanese knotweed (Reynoutria japonica Houtt.) were conducted in the Wigry National Park in 2017-2018, and in the Tatra National Park in 2018. Disease symptoms as spots on the leaves occurred in 2018. The following fungi were isolated from the spots: Alternaria alternata, Aureobasidium pullulans, Cladosporium cladosporioides, Epicoccum nigrum, Phomopsis velata and Phaeosphaeria sp. Alternaria alternata dominated in the material collected from Wigry National Park whereas $A$. pullulans and $C$. cladosporioides were isolated the most from the leaves originating from the Tatra National Park. This report is the first description of the organisms causing leaf diseases of the Japanese knotweed plants growing in Poland.

Key words: fungi, leaf spots, diseases of Japanese knotweed, Wigry, Tatra Mts.

\section{Streszczenie}

Badania fitopatologiczne prowadzono w latach 2017-2018 w Wigierskim Parku Narodowym oraz w 2018 roku w Tatrzańskim Parku Narodowym. W drugim roku badań stwierdzono występowanie objawów chorobowych na liściach rdestowca ostrokończystego (Reynoutria japonica Houtt.) w postaci plam. Z plam wyizolowano łącznie 6 taksonów grzybów: Alternaria alternata, Aureobasidium pullulans, Cladosporium cladosporioides, Epicoccum nigrum, Phomopsis velata i Phaeosphaeria sp. W Wigierskim Parku Narodowym dominował grzyb A. alternata, z kolei z plam rdestowca rosnącego w Tatrzańskim Parku Narodowym wyosobniono w największym stopniu A. pullulans i $C$. cladosporioides. Niniejsze doniesienie jest pierwszym opisem organizmów powodujących choroby liści rdestowca ostrokończystego w Polsce.

Słowa kluczowe: grzyby, plamistości liści, choroby rdestowca ostrokończystego, Wigry, Tatry

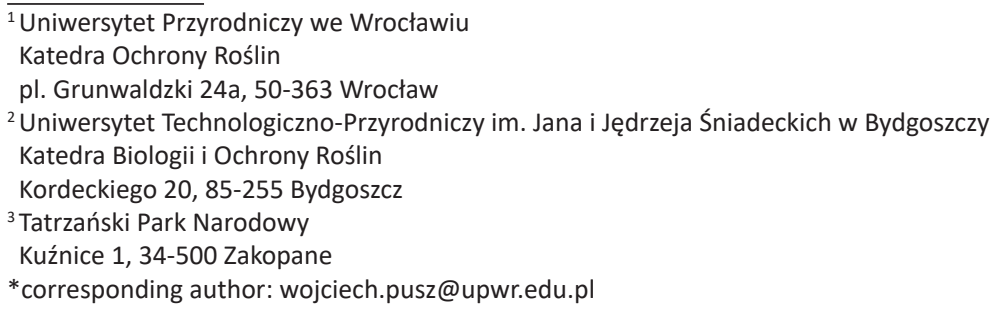




\section{Wstęp / Introduction}

Problem inwazji obcych gatunków na nowe tereny przykuwa uwagę uczonych od lat. Ranga zjawiska w latach 80. XX wieku urosła do stopnia, w którym zaczęto wyodrębniać je jako najpoważniejszy problem w ochronie przyrody, nadając mu status osobnej dziedziny nauki (Najberek i Solarz 2016). Temat przeciwdziałania inwazji obcych gatunków poruszają liczne akty prawne oraz umowy międzynarodowe między innymi Konwencja o Różnorodności Biologicznej (2002), a także unijna strategia ochrony różnorodności biologicznej na okres do 2020 r. (Sienkiewicz 2013). Zakładają one zidentyfikowanie oraz skategoryzowanie wiedzy na temat metod rozprzestrzeniania się organizmów inwazyjnych, likwidację i ograniczenie gatunków priorytetowych, a także ustalenie kompleksowych ram prawnych. Zapobieganie niekontrolowanemu rozprzestrzenianiu się organizmów inwazyjnych wymaga jednak szerokiego zrozumienia tematu inwazji oraz zebrania specjalistycznej wiedzy na temat każdego gatunku (Tokarska-Guzik i wsp. 2012).

Północ naszego kraju odznacza się większą podatnością na wystąpienie roślin obcych. Spośród Parków Narodowych największą liczbę gatunków obcych odnotowano właśnie w Wigierskim Parku Narodowym - 72 gatunki, w tym 11 gatunków inwazyjnych (Najberek i Solarz 2016). Co ciekawe, nie jest to jednak obszar najbardziej podatny na inwazję. Rośliny inwazyjne znacznie lepiej radzą sobie w miejscach silnie zmienionych przez człowieka, takich jak Górny i Dolny Śląsk, Opolszczyzna czy Małopolska (Dajdok i wsp. 2007). Daje to realną możliwość walki z nimi na terenie Wigierskiego Parku Narodowego oraz ograniczenie ich negatywnego oddziaływania na środowisko.

Rośliny inwazyjne na terenie Wigierskiego Parku Narodowego stwierdzono w różnych siedliskach. Największą ich presję zaobserwować można było na terenach ruderalnych, zasiedlanych między innymi przez Reynoutria japonica, Rosa rugosa oraz Solidago sp. Duże znaczenie mają również drogi śródleśne, stanowiące tranzyt między terenami naturalnymi a ruderalnymi, przy których oprócz wyżej wymienionych gatunków spotkać można między innymi Acer negundo, Quercus rubra oraz Prunus serotina. Gatunki te wraz z niecierpkiem drobnokwiatowym dobrze odnajdują się w środowisku leśnym, zajmując tereny borów, grądów, łęgów, a nawet borealnej bagiennej świerczyny. Ze względu na duży udział wód w Wigierskim Parku Narodowym niektóre rośliny inwazyjne szczególnie zadomowiły się przy obrzeżach rzek oraz jezior, wymienić wśród nich można: Impatiens parviflora, A. negundo oraz R. rugosa (Dajdok i wsp. 2007).

Rdestowiec ostrokończysty (Reynoutria japonica Houtt.) jest uważany za jeden z najgroźniejszych dla flory rodzimej gatunków roślin inwazyjnych (Tokarska-Guzik i wsp. 2012). Znacząco wpływa na zmiany składu ga- tunkowego fitocenoz, co skutkuje powstawaniem zbiorowisk o zubożałym składzie gatunkowym (Kowalczyk 2009). Najbardziej rozpowszechnioną metodą ograniczania populacji $R$. japonica jest obecnie metoda mechaniczna, polegająca na koszeniu i usuwaniu biomasy tej rośliny (Tokarska-Guzik i wsp. 2009). Jednak pojawia się problem ze składowaniem biomasy tego gatunku, a także $\mathrm{z}$ niską efektywnością tej metody z powodu zalegania kłączy na głębokości nawet do kilku metrów, co wiąże się z wysokimi kosztami usunięcia całej rośliny z danej powierzchni (Alberternst i Böhmer 2011; Dajdok i wsp. 2011). Niektórzy jednak upatrują przyszły sukces w ograniczaniu napływu roślin inwazyjnych, w tym i $R$. japonica ze strony wrogów naturalnych. Pojedyncze doniesienia mówią o wykorzystaniu do ograniczania populacji rdestowca ostrokończystego fitofagów (Pyšek 2006; Djeddour i wsp. 2008; Shaw i wsp. 2009) oraz grzybów (Kurose i wsp. 2012, 2015).

Celem niniejszych badań była ocena zdrowotności liści $R$. japonica w wybranych lokalizacjach na terenie dwóch polskich parków narodowych - Tatrzańskiego i Wigierskiego.

\section{Materiały i metody / Materials and methods}

Obserwacje zdrowotności $R$. japonica prowadzono w odstępach comiesięcznych, od maja do końca października na terenie Tatrzańskiego Parku Narodowego (TPN) w 2018 roku i Wigierskiego Parku Narodowego (WPN) w latach 2017-2018. W przypadku TPN oceniano zdrowotność zwartego łanu tej rośliny, rosnącej na stanowisku ruderalnym w rejonie Kuźnic - Spichlerza (49.272133 N, 19.982367 E), a także wzdłuż Drogi Balzera u wylotu Doliny Olczyskiej (Jaszczurówka) (49.284608 N, 20.000624 E). $\mathrm{Z}$ kolei na terenie WPN badaniami objęto osobniki rosnące przy Centrum Edukacji Środowiskowej na Słupiu $(54.0217 \mathrm{~N}, 23.051417$ E) oraz w rejonie Leśniczówki Słupie (54.023417 N, 23.04665 E).

W celu wyizolowania grzybów z porażonych organów podczas każdego wyjazdu terenowego pobierano fragmenty tkanek z wyraźnymi objawami porażenia. Z tkanek wycinano zmienione chorobowo fragmenty, które następnie były odkażane powierzchniowo w $0,5 \%$ roztworze podchlorynu sodu przez 10 sekund. Kolejnym etapem było wyłożenie około $0,5 \mathrm{~cm}$ fragmentów tkanki na szalki Petriego z zestaloną pożywką PDA (Potato Dextrose Agar, Difco). Wyrastające kolonie grzybów były odszczepiane na skosy z pożywką PDA i oznaczane do gatunku na podstawie cech morfologicznych oraz molekularnych (Pitt i Hocking 1997).

Czyste kultury poszczególnych izolatów hodowano na płytkach Petriego z pożywką glukozowo-ziemniaczaną PDA w ciemności, przez 1-2 tygodnie, w zależności od gatunku grzyba, w temperaturze $23^{\circ} \mathrm{C}$. Następnie z pożywki 
przerośniętej grzybnią wycięto po 3 krążki o średnicy $5 \mathrm{~mm}$ i przeniesiono je do płytek Petriego z płynną pożywką glukozowo-ziemniaczaną PDB (Potato Dextrose Broth, A\&A Biotechnology) i zabezpieczono parafilmem. Uzyskaną po 5-7 dniach grzybnię przepłukano wodą sterylną, odsączono przy użyciu zestawu filtracyjnego składającego się z bibuły filtracyjnej, lejka Büchnera i pompy próżniowej, a następnie liofilizowano przez 48 godzin w liofilizatorze CoolSafe (Scanvac). DNA ekstrahowano z grzybni poddanej homogenizacji przy użyciu kwarcowych kulek i piasku kwarcowego w homogenizatorze MagnaLyser (Roche).

Izolację DNA przeprowadzono według zmodyfikowanej metody Doyle i Doyle (1990). Użyto $900 \mu$ l buforu ekstrakcyjnego, który zawierał CTAB 5,0\%, EDTA 0,5 M, NaCl $5,0 \mathrm{M}$, Tris- $\mathrm{HCl}(\mathrm{pH} \mathrm{8,0)} \mathrm{1,0} \mathrm{M,} \beta$-merkaptoetanol i PVP $2,0 \%$. W kolejnych etapach użyto fenolu, chloroformu i alkoholu izoamylowego, a także alkoholu etylowego. Uzyskane DNA zawieszono w $100 \mu \mathrm{l} \mathrm{ddH}_{2} \mathrm{O}$. DNA zmierzono fluorometrycznie na urządzeniu Quantus (Promega), do dalszych analiz rozcieńczono $\mathrm{w} \mathrm{ddH}_{2} \mathrm{O}$ do stężenia $10 \mathrm{ng} / \mu \mathrm{l}$ i przechowywano $\mathrm{w}$ temperaturze $-20^{\circ} \mathrm{C}$.

Reakcję PCR (polymerase chain reaction) mającą na celu amplifikację regionów ITS przeprowadzono w objętości 37,5 $\mu$ zawierającej odczynniki PCR Core Kit (QIAGEN, USA): 1x Bufor, 1x roztwór Q, $1 \mathrm{mM} \mathrm{MgCl}_{2}$, 0,2 mM dNTP, 0,6 pM każdego z dwóch starterów (ITS1: 5'-TCCGTAGGTGAACCTGCGG-3' oraz ITS4: 5'-TCC TCCGCTTATTGATATGC-3') (White i wsp. 1990) oraz DNA o stężeniu $10 \mathrm{ng} / \mu \mathrm{l}$. DNA amplifikowano w urządzeniu Eppendorf EPMastercycler według protokołu reakcyjnego: denaturacja wstępna $\mathrm{w} 94^{\circ} \mathrm{C}-5 \mathrm{~min}$, 35 cykli $\left(94^{\circ} \mathrm{C}-1 \mathrm{~min}, 52^{\circ} \mathrm{C}-1 \mathrm{~min}, 72^{\circ} \mathrm{C}-2 \mathrm{~min}\right)$ i końcowe wydłużanie $\mathrm{w} 72^{\circ} \mathrm{C}-5 \mathrm{~min}$. Obecność produktów reakcji zweryfikowano po rozdziale elektroforetycznym w buforze TBE, przeprowadzonym na 1,2\% żelu agarozowym (Pronadisa) z dodatkiem barwnika SimplySafe $\left(\right.$ EUR $\left._{\mathrm{X}}\right)$ nanosząc po $2 \mu \mathrm{l}$ mieszaniny poreakcyjnej.

Produkty amplifikacji zostały oczyszczone i zsekwencjonowane przez Genomed (Polska). Do analizy otrzymanych sekwencji użyto programu FinchTV 1.4. Analizę ClustalW przeprowadzono w Mega7 Toolbar (Kumar i wsp. 2018). Do identyfikacji gatunkowej na podstawie kontigów sekwencji ITS wykorzystano Basic Local Alignment Search Tool (BLAST) w bazie NCBI (The National Center for Biotechnology Information).

\section{Wyniki i dyskusja / Results and discussion}

Pierwsze objawy chorobowe na stanowiskach zlokalizowanych w Tatrzańskim Parku Narodowym zaobserwowano na liściach $R$. japonica w pierwszej dekadzie czerwca. $\mathrm{Na}$ liściach pojawiły się drobne, owalne, ciemnobrunatne plamy o średnicy około $0,5-1 \mathrm{~cm}$. Plamy występowały na wszystkich liściach zwartego łanu $R$. japonica, który rósł w Kuźnicach. Natomiast na osobnikach rosnących wzdłuż drogi w Jaszczurówce, plamy występowały tylko na około $10 \%$ liściach. Na liściach widoczne były pojedyncze plamy. W kolejnych miesiącach prowadzenia obserwacji nie obserwowano wzrostu stopnia porażenia. Notowano jedynie powiększanie się rozmiaru poszczególnych plam, z których największe osiągały $2 \mathrm{~cm}$ średnicy. $Z$ kolei pierwsze objawy na liściach $R$. japonica rosnącego w Wigierskim Parku Narodowym pojawiły się na osobnikach rosnących w okolicy Leśniczówki Słupie w sierpniu. Ich średnica wynosiła około $1 \mathrm{~cm}$, zajmowały do $10 \%$ powierzchni blaszki liściowej i notowano ich obecność na każdym liściu. Podobna sytuacja miała miejsce na stanowisku przy Centrum Edukacyjnym w Słupiu. W kolejnych miesiącach nie stwierdzono zwiększonego nasilenia występowania objawów - rosła jedynie średnica plam do około $2 \mathrm{~cm}$. Podczas prowadzenia obserwacji zdrowotności nie stwierdzono innych objawów chorobowych zarówno na liściach, jak i pędach $R$. japonica.

$\mathrm{Z}$ występujących na liściach $R$. japonica plam wyosobniono łącznie 6 gatunków grzybów (tab. 1). Nie stwierdzono wyraźnej dominacji któregokolwiek z gatunków. Plamy zasiedlone były przez Alternaria alternata, Aureobasidium pullulans, Cladosporium cladosporioides, Epicoccum nigrum, Phomopsis velata oraz grzyba z rodzaju Phaeosphaeria sp. Najliczniej izolowanym z porażonych liści $R$. japonica był saprotrof, uważany także za wtórnego patogena - grzyb A. alternata (stanowił blisko $80 \%$ wszystkich wyizolowanych kolonii uzyskanych z Wigierskiego Parku Narodowego). Jest to takson często izolowany zarówno z żywych, jak i uszkodzonych tkanek, doprowadzający czasami do patogenezy i wystąpienia objawów chorobowych u roślin (Pusz 2016). Interesujący jest fakt, że A. alternata dominował w mykobiocie porażonych liści rdestowca rosnącego na terenie Wigierskiego Parku Narodowego, natomiast na osobnikach pochodzących z Tatrzańskiego Parku Narodowego, stanowił nieco ponad 14\%. Na tym obszarze największym udziałem w ogólnej liczbie kolonii wyosobnionych z plam na liściach $R$. japonica charakteryzował się A. pullulans oraz C. cladosporioides. Obydwa te gatunki stanowiły razem blisko $60 \%$ izolatów. Aureobasidium pullulans jest ważnym epi- i endofitem, który poprzez syntezę polisacharydów, w tym pullulanu, buduje naturalny biofilm na powierzchni rośliny, chroniący ją przed atakiem innych mikroorganizmów (Marcinkowska 2012; Chlebicki 2015). Cladosporium cladosporioides, będący jednym z najczęściej izolowanych taksonów ze środowiska, uważany jest za jednego ze sprawców plamistości liści (Ogórek i wsp. 2012). Jednak głównym miejscem jego występowania jest rozkładająca się materia organiczna i żywe tkanki roślin, które może wtórnie zasiedlać jako słaby patogen (Bensch i wsp. 2018). Interesujący jest również fakt wystąpienia $P$. velata na liściach $R$. japonica w Wigierskim 
Tabela 1. Grzyby wyizolowane z plam występujących na liściach rdestowca ostrokończystego (Reynoutria japonica) [\%] Table 1. The fungi isolated from leaf spots of Reynoutria japonica [\%]

\begin{tabular}{|c|c|c|c|c|c|}
\hline $\begin{array}{l}\text { Gatunek } \\
\text { Taxa }\end{array}$ & $\begin{array}{c}\text { Procent zgodności } \\
\text { z izolatami z NCBI } \\
\text { Identity with NCBI } \\
\text { isolates } \\
{[\%]}\end{array}$ & $\begin{array}{c}\text { Pokrycie analizowanej } \\
\text { sekwencji } \\
\text { z porównywaną } \\
\text { Query cover } \\
{[\%]}\end{array}$ & $\begin{array}{l}\text { Zgodność z sekwencją z NCBI } \\
\text { (max } 2 \text { przykłady) } \\
\text { Identity with NCBI isolates } \\
\text { (accession numbers) }\end{array}$ & $\begin{array}{c}\text { Tatrzański Park } \\
\text { Narodowy } \\
\text { Tatra National } \\
\text { Park }\end{array}$ & $\begin{array}{l}\text { Wigierski Park } \\
\text { Narodowy } \\
\text { Wigry National } \\
\text { Park }\end{array}$ \\
\hline $\begin{array}{l}\text { Alternaria } \\
\text { alternata }\end{array}$ & 100 & 100 & $\begin{array}{l}\text { MH931372.1, } \\
\text { MF141014.1 } \\
\text { MG250610.1, } \\
\text { MH879772.1 }\end{array}$ & 14,3 & 77,8 \\
\hline $\begin{array}{l}\text { Aureobasidium } \\
\text { pullulans }\end{array}$ & 99 & 100 & $\begin{array}{l}\text { MH931262.1, } \\
\text { MH858817.1 }\end{array}$ & 28,6 & - \\
\hline $\begin{array}{l}\text { Cladosporium } \\
\text { ladosporioides }\end{array}$ & 100 & 100 & $\begin{array}{l}\text { МH865207.1, } \\
\text { МH863533.1 }\end{array}$ & 28,6 & - \\
\hline $\begin{array}{l}\text { Epicoccum } \\
\text { nigrum }\end{array}$ & 100 & 100 & $\begin{array}{c}\text { MH860655.1, } \\
\text { MF380871.1 }\end{array}$ & 14,3 & - \\
\hline Phaeosphaeria sp. & 100 & 100 & EF485232.1 & 14,3 & - \\
\hline Phomopsis velata & 100 & 100 & $\begin{array}{l}\text { MH935025.1, } \\
\text { MG281108.1 }\end{array}$ & - & 22,2 \\
\hline
\end{tabular}

Parku Narodowym, gdzie stanowiło ponad 22\% wszystkich wyizolowanych kolonii. Gatunek ten, będący formą konidialną Diaporthe eres jest ważnym patogenem wywołującym nekrozy różnych gatunków roślin na całym świecie(Udayanga i wsp. 2014; Fan i wsp. 2018; Meepagala i wsp. 2018).

Jak podaje Kurose i wsp. (2012), wyodrębnione w badaniu gatunki, w naturalnej strefie występowania $R$. japonica występują jako endofity, niedoprowadzające do objawów chorobowych. Niektóre z nich, takie jak Alternaria spp. pełnić mogą funkcje ochronne przed obligatoryjnymi patogenami z rodziny Pucciniales, doprowadzając do mniejszego porażenia liści w naturalnej strefie ich występowania. Jak wykazuje jednak sam autor, wyizolowane gatunki grzybów nie doprowadzały do objawów chorobowych u gospodarza w czasie trwania badania, jednak pod wpływem czynników stresogennych możliwa jest zmiana relacji grzyb-roślina, doprowadzająca do rozpoczęcia procesu patogenezy (Schulz i Boyle 2005; Álvarez-Loayza i wsp. 2011; Kurose i wsp. 2012). Wysoce prawdopodobne jest zatem w obu przypadkach, że kompleks grzybów wyizolowany w obu lokalizacjach bezpośrednio doprowadził do powstania plamistości na liściach $R$. japonica, pod wpływem niekorzystnych warunków abiotycznych.

\section{Podsumowanie / Conclusions}

Z plam występujących na liściach rdestowca ostrokończystego ( $R$. japonica) wyosobniono zarówno patogeny (A. alternata, C. cladosporioides), jak i grzyby niepowodujące objawów chorobowych. Niniejsze opracowanie jest pierwszym w Polsce stwierdzeniem i opisaniem grzybów powodujących plamistości liści na $R$. japonica. Konieczne są dalsze badania, które mogą dać odpowiedź na pytanie, jaką rolę pełnią grzyby wyizolowane z plam oraz czy mogą one stanowić w przyszłości jeden $\mathrm{z}$ elementów ograniczających rozprzestrzenianie się tego gatunku w naszym kraju. Możliwe jest również, że stwierdzenie występowania chorób na liściach oraz mykobioty je zasiedlającej, świadczy o przejściu w kolejną fazę „inwazji” rdestowca ostrokończystego w Polsce oraz procesie jego udomowienia.

Badania dofinansowano ze środków funduszu leśnego, w ramach umowy zawartej pomiędzy Państwowym Gospodarstwem Leśnym Lasy Państwowe a Wigierskim Parkiem Narodowym (EZ.0290.1.36.2018 - Działanie nr 4) i Tatrzańskim Parkiem Narodowym (EZ.0290.1.32.2018).

\section{Literatura / References}

Alberternst B., Böhmer H.J. 2011. NOBANIS - Invasive Alien Species Fact Sheet - Fallopia japonica. Online Database of the North European and Baltic Network onInvasive Alien Species. www.nobanis.org [dostęp: 2.11.2018].

Álvarez-Loayza P., White J.F. Jr, Torres M.S., Balslev H., Kristiansen T., Svenning J.-C., Gil N. 2011. Light converts endosymbiotic fungus to pathogen, influencing seedling survival and niche-space filling of a common tropical tree, Iriartea deltoidea. PLoS ONE 6 (1): e16386. DOI: 10.1371/journal.pone.0016386. 
Bensch K., Groenewald J.Z., Meijer M., Dijksterhuis J., Jurjević Ž., Andersen B., Houbraken J., Crous P.W., Samson R.A. 2018. Cladosporium species in indoor environments. Studies in Mycology 89: 177-301. DOI: 10.1016/j.simyco.2018.03.002.

Chlebicki A. 2015. Biofilmy występują powszechnie w przyrodzie. [Biofilms commonly occur in nature]. Komos 64 (2): $337-345$.

Dajdok Z., Krzysztofiak A., Krzysztofiak L., Romański M., Śliwiński M. 2007. Rośliny inwazyjne w Wigierskim Parku Narodowym. Wigierski Park Narodowy, Krzywe, 24 ss.

Dajdok Z., Śliwiński M., Romański M., Krzysztofiak A., Krzysztofiak L. 2011. Gatunki inwazyjne jako zagrożenie dla bioróżnorodności. W: Poradnik dla pracowników parków narodowych. Edycja 4. Wigierski Park Narodowy. http://www.wigry.org.pl/inf_i_rozw/budowa_por/por4_4.htm [dostęp: 13.10.2018].

Djeddour D.H., Shaw R.H., Evans H.C., Tanner R.A., Kurose D., Takahashi N., Seier M. 2008. Could Fallopia japonica be the first target for classical weed biocontrol in Europe? XII International Symposium on Biological Control of Weeds: 463-469.

Doyle J.J., Doyle J.L. 1990. Isolation of plant DNA from fresh tissue. Focus 12 (1): 13-15.

Fan X.L., Yang Q., Bezerra J.D.P., Alvarez L.V., Tian C.M. 2018. Diaporthe from walnut tree (Juglans regia) in China, with insight of the Diaporthe eres complex. Mycological Progress 17 (7): 841-853. DOI: 10.1007/s11557-018-1395-4.

Konwencja o Różnorodności Biologicznej. 2002. Dz.U. 2002 nr 184, poz. 1532.

Kowalczyk B. 2009. Rdestowiec japoński (Reynoutria japonica Houtt.) - gatunek inwazyjny i leczniczy - rozprzestrzenianie się w gminie Krzyżanowice (Kotlina Raciborska). [Japanese knotweed (Reynoutria japonica Houtt.) - invasive alien and medical plant - distribution in the commune Krzyżanowice (Raciborska Valley)]. Annales Academiae Medicae Silesiensis 63 (6): 48-53.

Kumar S., Stecher G., Li M., Knyaz C., Tamura K. 2018. MEGA X: molecular evolutionary genetics analysis across computing platforms. Molecular Biology and Evolution 35 (6): 1547-1549. DOI: 10.1093/molbev/msy096.

Kurose D., Furuya N., Seier M.K., Djeddour D.H., Evans H.C., Matsushita Y., Tsuchiya K., Tsushima S. 2015. Factors affecting the efficacy of the leaf-spot fungus Mycosphaerella polygoni-cuspidati (Ascomycota): A potential classical biological control agent of the invasive alien weed Fallopia japonica (Polygonaceae) in the UK. Biological Control 85: 1-11. DOI: 10.1016/j.biocontrol.2015.03.002.

Kurose D., Furuya N., Tsuchiya K., Tsushima S., Evans H.C. 2012. Endophytic fungi associated with Fallopia japonica (Polygonaceae) in Japan and their interactions with Puccinia polygoni-amphibii var. tovariae, a candidate for classical biological control. Fungal Biology 116 (7): 785-791. DOI: 10.1016/j.funbio.2012.04.011.

Marcinkowska J. 2012. Oznaczanie rodzajów grzybów sensu lato ważnych w fitopatologii. Powszechne Wydawnictwo Rolnicze i Leśne, Warszawa, 508 ss.

Meepagala K.M., Briscoe W.E., Techen N., Johnson R.D., Clausen B.M., Duke S.O. 2018. Isolation of a phytotoxic isocoumarin from Diaporthe eres-infected Hedera helix (English ivy) and synthesis of its phytotoxic analogs. Pest Management Science 74 (1): $37-45$. DOI: $10.1002 /$ ps.4712.

Najberek K., Solarz W. 2016. Gatunki obce. Przyczyny inwazyjnych zachowań i sposób zwalczania. [Alien species. Causes of invasiveness and control methods]. Kosmos Problemy Nauk Biologicznych 65 (1) 310: 81-91.

Ogórek R., Lejman A., Pusz W., Miłuch A., Miodyńska P. 2012. Characteristics and taxonomy of Cladosporium fungi. [Charakterystyka i taksonomia grzybów z rodzaju Cladosporium]. Mikologia Lekarska 19 (2): 80-85.

Pitt J.I., Hocking A.D. 1997. Fungi and Food Spoilage. Blackie Academic and Professional, London, New York, 593 ss.

Pusz W. 2016. Plants' healthiness assessment as part of the environmental monitoring of protected mountainous area in the example of Karkonosze (Giant) Mts. (SW Poland). Environmental Monitoring and Assessment 188 (10): 544. DOI: 10.1007/s10661-016$5551-5$.

Pyšek P. 2006. Fallopia japonica. DAISIE, Delivering Alien Invasive Species Inventories for Europe. http://www.europe-aliens.org [dostęp: 15.12.2013].

Schulz B., Boyle C. 2005. The endophytic continuum. Mycological Research 109: 661-686.

Shaw R.H., Bryner S., Tanner R. 2009. The life history and host range of the Japanese knotweed psyllid, Aphalara itadori Shinji: potentially the first classical biological weed control agent for the European Union. Biological Control 49 (2): 105-113. DOI: 10.1016/j. biocontrol.2009.01.016.

Sienkiewicz J. 2013. Ochrona różnorodności biologicznej w krajach UE do 2020 r. - nowa strategia europejska. [Biodiversity conservation in ue countries until 2020 - new european strategy]. Polish Journal of Agronomy 14: 45-52.

Tokarska-Guzik B., Bzdęga K., Tarłowska S., Koszela K. 2009. Gatunki z rodzaju rdestowiec Reynoutria spp. W: Inwazyjne gatunki roślin ekosystemów mokradłowych Polski (Z. Dajdok, P. Pawlaczyk, red.). Wydawnictwo Klubu Przyrodników, Świebodzin: 87-99.

Tokarska-Guzik B., Dajdok Z., Zając M., Zając A., Urbisz A., Danielewicz W., Hołdyński C. 2012. Rośliny obcego pochodzenia w Polsce ze szczególnym uwzględnieniem gatunków inwazyjnych. Generalna Dyrekcja Ochrony Środowiska, Warszawa, 197 ss.

Udayanga D., Castlebury L.A., Rossman A.Y., Chukeatirote E., Hyde K.D. 2014. Insights into the genus Diaporthe: phylogenetic species delimitation in the D. eres species complex. Fungal Diversity 67 (1): 203-229. DOI: 10.1007/s13225-014-0297-2. 